\title{
健康増進事業による受講者の栄養状態改善効果
}

南里明子* · 早㴊仁美* ·太田雅規** · 久野真奈見* ·平川史子* · 松永泰子* ·池田正春**

(*福岡女子大学大学院栄養保健科学, **産業医科大学産業生態科学研究所)

\section{Effects of health and nourishment guidance on the participants' health status in a community-based health promotion program}

\author{
Akiko Nanri*, Hitomi Hayabuchi*, Masanori Ohta**, Manami Hisano*, \\ Fumiko Hirakawa*, Yasuko Matsunaga*, Masaharu Ikeda** \\ *Faculty of Human Environmental Science, Fukuoka Women's University, 1-1-1, Kasumigaoka, \\ Higashi-ku, Fukuoka-shi, 813-8529 \\ **Institute of Industrial Ecological Sciences, University of Occupational and Environmental Health, \\ 1-1, Iseigaoka, Yahatanishi-ku, Kitakyushu-shi, 807-8555 \\ *干813-8529 福岡市東区香住丘 1-1-1 \\ **厂 $807-8555$ 北九州市八幡西区医生ヶ丘 1-1
}

The purpose of this study was to investigate the effects of health and nourishment guidance on the participants' health status in a community-based health promotion program.

Subjects were recruited from participants in a 12 -week lifestyle modification program for reducing cardiovascular risk factors, such as obesity, hypertension and dyslipidemia. Subjects were middle-aged women ranging from 36 to 64 years old without obvious heart disease. The intervention consisted of guidance in exercise and nutrition for 12 weeks.

After the 12-week intervention, body weight, BMI, percentage of fat, total cholesterol and triglycerides significantly decreased. The systolic and diastolic blood pressure was significantly lowered. The HDL-cholesterol and maximum oxygen consumption significantly increased.

The results of the dietary habit analysis confirmed that many items have improved regarding obesity. For those with hypertension, whose dietary habits were desirable, showed improvements in the items of intake of vegetable, fruits and salt after the intervention.

These results indicated that a 12 -week lifestyle modification program consisting of exercise and nutritional guidance, effectively improved this dietary life.

In conclusion, the implementation of a health promotion program provided a chance for the participants to reconsider and improve their lifestyle.

\section{緒言}

内臓脂肪型肥満や高血圧, 高血糖, 脂質異常は, 軽症 でも複数併せもった状態をメタボリックシンドロームと 呼び，メタボリックシンドロームへの対策が，生活習慣 病の発症を予防できると期待されている11。わが国にお
いては, 「健康日本 $21 」^{2)}$ への取り組みや, 健康増進法の 制定など，生活習慣病対策が進められているが，メタボ リックシンドロームの考え方を取り入れた更なる対策が 課題とされている3)。

北九州市では, 中高年男女を対象に, 肥満や高血圧等 の生活習慣病の改善を目的とした健康増進教室が実施さ 
れている。本研究では, 北九州市の健康増進施設と大学 等研究機関が, 肥満や高血圧等, 生活習慣病の境界域に ある市民を対象として行った健康増進教室の指導効果を 明らかにするために, 受講者の指導前と指導後の栄養状 態を比較し, 指導の改善効果について検討したので報告 する。

\section{方法}

\section{1. 解析対象}

解析対象は，1994年から1998年度に実施された北九州 市健康増進事業の受講者で, 問診が指導前後揃っていた 年齢36 64（平均士標準偏差 $=48.8 \pm 6.1$ ) 歳の女性 372 名である。なお，参加者には，インフォームド・コンセ ントとして, 研究の目的, 意義, 方法について説明を行 い, 本人の同意を得て行った。をた, 本研究は, 産業医 科大学倫理審査委員会の審査を受け, 承認を得て行った 研究の一部である。

本教室への参加条件は, BMI (Body Mass Index) 25.0 $\mathrm{kg} / \mathrm{m}^{2}$ 以上の肥満か, 収縮期血圧 $140 \mathrm{mmHg}$ 以上また は拡張期血圧 $90 \mathrm{mmHg}$ 以上の高血圧を有する人で, 明 らかな心臓疾患がないことであった。

\section{2. 健康増進教室における実施内容}

北九州市の健康増進施設に抒いて，12週間継続して栄 養, 運動等に関する指導が行われ, 健康増進教室の開始 前と終了時に医学検査と問診調査が実施された。

\section{$2-1$ 栄養指導}

栄養指導は期間中に 2 度実施された。まず，健康増進 教室開始時に健診結果と栄養問診結果に基づき，管理栄 養士により, (1)主食·主菜·副菜をそろえ, 多種類の食 品を摂取して栄養バランスをとること, (2)欠食せず，間 食を控え, 規則正しい食生活をすること, (3)脂肪は量と 質に注意すること，(4)食塩は 1 日 $10 \mathrm{~g}$ 以下を目標に減塩 に努めることなどの食生活指導が行われ，個人別に食生 活目標を設定し, 毎日守れたかどうかを記録させ, 本教 室開始 6 週後にも指導が行われた。

\section{2-2 運動指導}

対象者の年齢, 症例その他属性に応じて, 健康運動指 導土等が参加者個人別に作成するプログラムにより, 自 転車エルゴメーター，ウォーキングを主体とした「にこ にこペース」による有酸素主導の運動指導が行われた。

週 3 回を原則とし，施設での指導はそのうち $2 \sim 3$ 回で, 各 1 時間程度とし, 週 3 回に満たない人は残り 1 回は自 宅周辺でのウォーキングなどの指導が行われた。

\section{2 - 3 医学検査}

身長, 体重, 体脂肪率（インピーダンス法・ TBF501 ; タニタ製), 自転車エルゴメータ（ML-1800；フ クダ電子製）による運動負荷テストから最大酸素拱取量 を求め, 血圧の測定（BP-203RV; 日本コーリン製）と, 血液検査を行った。なお，血液検査は，総コレステロー
ル，中性脂肪は酵素法，HDL-コレステロールは酵素 . 直接法にて測定し, GOT, GPT, $\gamma$ GTPは, 生化学自 動分析機にて測定した。

\section{2-4 問診調査}

健康増進教室の開始前と終了時に, 食習慣, 生活満足 度, 健康管理, 自覚症状, 生活習慣, 運動習慣について の項目から成る問診調査が実施された。食習慣について の問診は, 食生活に関する質問20項目, 食品等摂取31項 目，その他飲料やサプリメント等に関する項目の計74項 目で構成されている。

\section{3. 解析方法}

女性では, 閉経により様々な生理的変化が生じ4) 7), 閉経年齢が50歳前後である6),7)ことから, 対象者を50歳 未満と50歳以上に分けて検討した。また, BMI $25 \mathrm{~kg} / \mathrm{m}^{2}$ 以上の肥満群とそれ以外の非肥満群, 収縮期血圧 $140 \mathrm{mmHg}$ 以上または拡張期血圧 $90 \mathrm{mmHg}$ 以上の高血 圧群とそれ以外の非高血圧群のそれぞれ 2 群に分け, 指 導前後の変化を検討した。医学検査值については, 指導 前後の平均土標準偏差を示し, 対応のある $\mathrm{t}$ 検定を行い, $5 \%$ 以下を有意水準として变化の程度を明らかにした。

食習慣問診結果の指導前後の变化については，50歳未 満・以上で同じような傾向を示していたため, 全対象者 の結果をまとめ, 肥満群/非肥満群及び高血圧群/非高血 圧群のそれぞれ 2 群に分け，指導前後の変化を検討した。 なお，選択肢が 2 つ以上ある項目については，選択肢を $2 つ($ Yes またはNo）にまとめ, ロジスティック回帰 分析を行い検討した。集計及び解析には, SAS Institute Japan (制製 JMP.4J を用いた。

\section{結果}

\section{1．対象者の身体特性}

対象者の身体特性を表 1 に示す。受講前の対象者の BMI 平均值と標準偏差は, 50歳未満, 50歳以上の順に $27.4 \pm 3.5 \mathrm{~kg} / \mathrm{m}^{2}, 26.5 \pm 3.5 \mathrm{~kg} / \mathrm{m}^{2}$ であり, 肥満者の 割合は $80.1 \%, 67.4 \%$ であった。また, 収縮期血圧は順 に134.7 $\pm 18.9 \mathrm{mmHg}, 139.3 \pm 17.2 \mathrm{mmHg}$, 拡張期血 圧は $82.3 \pm 11.3 \mathrm{mmHg}, 82.5 \pm 10.8 \mathrm{mmHg}$ であり, 高 血圧者の割合は $41.9 \%, 58.6 \%$ あった。

\section{2. 身体特性の指導前後の変化 \\ $2-1$ 年代別}

年代別の身体特性の指導前後の変化を表 1 に示す。 50 歳未満 · 以上とも体脂肪率, 血圧, 総コレステロールや GPT 等で有意な減少が認められた。一方, 最大酸素摂 取量と HDL-コレステロールは, 指導後有意に増加して おり, 多くの項目で改善が認められた。表には示してな いが, 指導前後の体重の変化率は, 50 歳未満·以上の順 に $-3.9 \pm 3.7 \%,-3.5 \pm 3.0 \%$, 平均血圧の变化率は, $-5.5 \pm 10.3 \%,-6.3 \pm 10.6 \%$ であった。 50 歳未満・以 


\begin{tabular}{|c|c|c|c|c|c|}
\hline \multirow[b]{2}{*}{ 特性 } & & \multicolumn{2}{|c|}{ 50歳未満（n=191） } & \multicolumn{2}{|c|}{ 50歳以上 $(n=181)$} \\
\hline & & 指導前 & 指導後 & 指導前 & 指導後 \\
\hline 体重 & $(\mathrm{kg})$ & $65.5 \pm 9.02$ & $62.9 \pm 8.49 * * *$ & $62.4 \pm 8.66$ & $60.2 \pm 8.01^{* * *}$ \\
\hline BMI & $\left(\mathrm{kg} / \mathrm{m}^{2}\right)$ & $27.4 \pm 3.50$ & $26.3 \pm 3.30^{* * *}$ & $26.5 \pm 3.54$ & $25.6 \pm 3.29 * * *$ \\
\hline 体脂肪率 & $(\%)$ & $34.3 \pm 5.39$ & $32.6 \pm 5.45^{* * *}$ & $33.5 \pm 6.08$ & $32.3 \pm 5.86^{* * *}$ \\
\hline 収縮期血圧 & $(\mathrm{mmHg})$ & $134.7 \pm 18.92$ & $126.1 \pm 15.98^{* * *}$ & $139.3 \pm 17.23$ & $128.3 \pm 16.00^{* * *}$ \\
\hline 拡張期血圧 & $(\mathrm{mmHg})$ & $82.3 \pm 11.32$ & $77.5 \pm 10.81^{* * *}$ & $82.5 \pm 10.81$ & $77.4 \pm 10.18^{* * *}$ \\
\hline 最大酸素摂取量 & (ml $/ \mathrm{kg} /$ 分) & $27.5 \pm 7.07$ & $33.1 \pm 7.57^{* * *}$ & $26.3 \pm 6.81$ & $31.7 \pm 6.72^{* * *}$ \\
\hline 総コレステロール & $(\mathrm{mg} / \mathrm{dl})$ & $214.3 \pm 35.60$ & $206.7 \pm 37.77^{* * *}$ & $230.0 \pm 34.71$ & $217.9 \pm 31.61^{* * *}$ \\
\hline HDL-コレステロール & $(\mathrm{mg} / \mathrm{dl})$ & $53.1 \pm 13.04$ & $56.7 \pm 12.63^{* * *}$ & $55.0 \pm 14.72$ & $58.2 \pm 15.02^{* * *}$ \\
\hline 中性脂肪 & $(\mathrm{mg} / \mathrm{dl})$ & $135.5 \pm 73.49$ & $110.2 \pm 95.20^{* * *}$ & $155.1 \pm 137.02$ & $109.3 \pm 59.13^{* * *}$ \\
\hline GOT & $(\mathrm{IU} / \mathrm{dl})$ & $21.3 \pm 10.60$ & $20.8 \pm 6.75$ & $23.8 \pm 9.51$ & $23.4 \pm 8.62$ \\
\hline GPT & (IU/dl) & $22.1 \pm 14.32$ & $19.7 \pm 11.57^{* *}$ & $24.3 \pm 16.97$ & $21.4 \pm 12.77^{* *}$ \\
\hline$\gamma \mathrm{GTP}$ & (IU/dl) & $23.1 \pm 30.16$ & $20.0 \pm 17.22$ & $24.0 \pm 19.10$ & $22.2 \pm 22.25$ \\
\hline 肥満者数※2 & $\mathrm{n}(\%)$ & $153(80.1)$ & $128(67.0)^{* *}$ & $122(67.4)$ & $101(55.8)^{*}$ \\
\hline 高血圧者数※3 & $\mathrm{n}(\%)$ & $80(41.9)$ & $53(27.7)^{* *}$ & $106(58.6)$ & $47(26.0) * * *$ \\
\hline
\end{tabular}

※1北九州市健康増進教室受講者で, 指導前後の問診結果が揃っていた女性全て

※2 $\mathrm{BMI} \geqq 25 \mathrm{~kg} / \mathrm{m}^{2}$

※3収縮期血圧 $\geqq 140 \mathrm{mmHg}$ または拡張期血圧 $\geqq 90 \mathrm{mmHg}$

${ }^{*} \mathrm{p}<0.05,{ }^{* *} \mathrm{p}<0.01, * * * \mathrm{p}<0.001 \quad$ （指導前後の変化 : 対応のある $\mathrm{t}$ 検定， $\chi^{2}$ 検定）

表 2 身体特性の指導前後の変化 一肥満※1または高血圧※2の有無別一

$(\mathrm{Mean} \pm$ S.D. $)$

\begin{tabular}{|c|c|c|c|c|c|}
\hline & & \multicolumn{2}{|c|}{ 非肥満者（n=97） } & \multicolumn{2}{|c|}{ 肥満者（n=275） } \\
\hline & & 指導前 & 指導後 & 指導前 & 指導後 \\
\hline 年齢 & （歳） & $50.2 \pm 5.51$ & & $48.3 \pm 6.16$ & \\
\hline 体重 & $(\mathrm{kg})$ & $54.6 \pm 5.35$ & $53.2 \pm 5.22^{* * *}$ & $67.3 \pm 7.50$ & $64.5 \pm 7.17^{* * *}$ \\
\hline BMI & $\left(\mathrm{kg} / \mathrm{m}^{2}\right)$ & $22.9 \pm 1.70$ & $22.3 \pm 1.64^{* * *}$ & $28.4 \pm 2.82$ & $27.3 \pm 2.73^{* * *}$ \\
\hline 体脂肪率 & $(\%)$ & $28.1 \pm 3.78$ & $27.3 \pm 4.20^{* *}$ & $35.9 \pm 4.86$ & $34.3 \pm 4.93^{* * *}$ \\
\hline 収縮期血圧 & $(\mathrm{mmHg})$ & $136.4 \pm 21.19$ & $126.5 \pm 17.59^{* * *}$ & $137.1 \pm 17.12$ & $127.4 \pm 15.43^{* * *}$ \\
\hline 拡張期血圧 & $(\mathrm{mmHg})$ & $81.3 \pm 12.54$ & $77.5 \pm 12.33^{* *}$ & $82.7 \pm 10.49$ & $77.5 \pm 9.79^{* * *}$ \\
\hline 最大酸素摂取量 & (ml/kg/分） & $28.5 \pm 7.15$ & $33.0 \pm 7.55^{* * *}$ & $26.3 \pm 6.82$ & $32.2 \pm 7.07^{* * *}$ \\
\hline 総コレステロール & $(\mathrm{mg} / \mathrm{dl})$ & $227.1 \pm 39.28$ & $219.0 \pm 36.08^{* *}$ & $220.1 \pm 34.65$ & $209.8 \pm 34.81^{* * *}$ \\
\hline HDL-コレステロール & $(\mathrm{mg} / \mathrm{dl})$ & $59.7 \pm 15.82$ & $62.2 \pm 16.58^{*}$ & $52.1 \pm 12.61$ & $55.8 \pm 12.37^{* * *}$ \\
\hline 中性脂肪 & $(\mathrm{mg} / \mathrm{dl})$ & $121.6 \pm 68.54$ & $99.9 \pm 66.87^{* *}$ & $153.1 \pm 119.04$ & $113.2 \pm 83.68^{* * *}$ \\
\hline GOT & $(\mathrm{IU} / \mathrm{dl})$ & $21.8 \pm 9.51$ & $21.9 \pm 6.80$ & $22.8 \pm 10.37$ & $22.1 \pm 8.14$ \\
\hline GPT & $(\mathrm{IU} / \mathrm{dl})$ & $18.5 \pm 10.52$ & $18.0 \pm 10.25$ & $24.8 \pm 16.82$ & $21.4 \pm 12.68^{* * *}$ \\
\hline \multirow[t]{2}{*}{$r$ GTP } & (IU/dl) & $23.8 \pm 34.16$ & $21.6 \pm 20.99$ & $23.4 \pm 21.58$ & $20.9 \pm 19.42^{* *}$ \\
\hline & & \multicolumn{2}{|c|}{ 非高血圧者（n=186） } & \multicolumn{2}{|c|}{ 高血圧者（n=186） } \\
\hline 年齢 & （歳） & $47.7 \pm 6.33$ & & $49.9 \pm 5.56$ & \\
\hline 体重 & $(\mathrm{kg})$ & $64.5 \pm 8.80$ & $62.1 \pm 8.28^{* * *}$ & $63.5 \pm 9.12$ & $61.0 \pm 8.43^{* * *}$ \\
\hline BMI & $\left(\mathrm{kg} / \mathrm{m}^{2}\right)$ & $27.1 \pm 3.44$ & $26.2 \pm 3.29 * * *$ & $26.8 \pm 3.64$ & $25.8 \pm 3.33^{* * *}$ \\
\hline 体脂肪率 & $(\%)$ & $34.1 \pm 5.40$ & $32.6 \pm 5.54^{* * *}$ & $33.7 \pm 6.07$ & $32.3 \pm 5.75^{* * *}$ \\
\hline 収縮期血圧 & $(\mathrm{mmHg})$ & $122.5 \pm 10.31$ & $119.5 \pm 13.78^{* *}$ & $151.3 \pm 11.97$ & $134.8 \pm 14.37 * * *$ \\
\hline 拡張期血压 & $(\mathrm{mmHg})$ & $74.9 \pm 7.55$ & $73.8 \pm 9.92$ & $89.9 \pm 8.67$ & $81.1 \pm 9.77^{* * *}$ \\
\hline 最大酸素摂取量 & (ml/kg/分） & $26.8 \pm 6.72$ & $32.2 \pm 6.62^{* * *}$ & $27.0 \pm 7.22$ & $32.7 \pm 7.76^{* * *}$ \\
\hline 総コレステロール & $(\mathrm{mg} / \mathrm{dl})$ & $221.0 \pm 34.61$ & $213.3 \pm 35.05^{* * *}$ & $222.8 \pm 37.40$ & $211.0 \pm 35.65^{* * *}$ \\
\hline HDL-コレステロール & $(\mathrm{mg} / \mathrm{dl})$ & $54.6 \pm 14.87$ & $57.6 \pm 14.43^{* * *}$ & $53.4 \pm 12.81$ & $57.2 \pm 13.22^{* * *}$ \\
\hline 中性脂肪 & $(\mathrm{mg} / \mathrm{dl})$ & $133.2 \pm 66.92$ & $110.9 \pm 81.99^{* * *}$ & $156.8 \pm 138.49$ & $108.6 \pm 77.75^{* * *}$ \\
\hline GOT & (IU/dl) & $21.5 \pm 8.31$ & $21.3 \pm 6.46$ & $23.6 \pm 11.64$ & $22.8 \pm 8.91$ \\
\hline GPT & (IU/dl) & $21.4 \pm 13.91$ & $19.5 \pm 11.69^{* *}$ & $25.0 \pm 17.10$ & $21.5 \pm 12.60^{* *}$ \\
\hline$\gamma \mathrm{GTP}$ & $(\mathrm{IU} / \mathrm{dl})$ & $19.8 \pm 14.77$ & $17.7 \pm 12.76^{*}$ & $27.3 \pm 32.40$ & $24.4 \pm 24.55$ \\
\hline
\end{tabular}

※1非肥満 $: \mathrm{BMI}<25 \mathrm{~kg} / \mathrm{m}^{2}$, 肥満 $: \mathrm{BMI} \geqq 25 \mathrm{~kg} / \mathrm{m}^{2}$

※2高血圧 : 収縮期血圧 $\geqq 140 \mathrm{mmHg}$ または拡張期血圧 $\geqq 90 \mathrm{mmHg}$, 非高血圧 : それ以外

${ }^{*} \mathrm{p}<0.05,{ }^{* *} \mathrm{p}<0.01,{ }^{* * *} \mathrm{p}<0.001 \quad$ (指導前後の変化 : 対応のある $\mathrm{t}$ 検定） 
上ともに，肥満者及び高血圧者は指導後有意に減少し， 全体では，肥満者は $73.9 \%$ から $61.6 \%$ に，高血圧者は50 \%から $26.9 \%$ に減少した。

\section{2- 2 肥満または高血圧有無別}

肥満をたは高血圧有無別の身体特性の指導前後の変化 を表 2 に示す。肥満群では非肥満群に比べ，最大酸素摂 取量, HDL-コレステロール, 中性脂肪に顕著な改善が 認められた。表には示してないが, 指導前後の体重変化 率は, 非肥満群 $-2.5 \pm 3.2 \%$, 肥満群 $-4.1 \pm 3.4 \%$ であ り，有意差が認められた $(\mathrm{p}<0.001)$ 。

高血圧有無別では, 両群とも多くの項目で改善が認め られたが，非高血圧群では拡張期血圧に有意な变化は認 められなかった。高血圧群では, 血圧や中性脂肪に顕著 な改善が認められた。平均血圧の変化率は, 非高血圧群 $-1.7 \pm 10.0 \%$, 高血圧群 $-10.1 \pm 9.1 \%$ であり, 有意差 が認められた $(\mathrm{p}<0.001)$ 。

\section{3. 食習慣の指導前後の変化}

\section{3-1 食意識}

食意識の指導前後の变化を図 1 に示す。指導前から年 代や肥満, 血圧状況にかかわらず，「食生活は健康に影 響を与える」と思う人が大半であったが，実際に「健康 のために食生活にとても気を付けている」と答えた人は, 3 割未満であった。しかし, 指導後は「食生活にとても 気を付けている」と答えた人が, 全体の半数以上に増加 した。

\section{3-2 食生活}

肥満または高血圧有無別の食生活で，指導前後有意に 変化した項目のみ表 3 に示す。指導前, 肥満群は非肥満 群に比べ，「気に入ったものを多量に」,「腹一杯」,「や け食い」，「全部食べないと気がすをない」人が有意に多 かったが，指導後有意に減少した。その他「余り料理」, 「夕食後の飲食」等の項目は, 指導後肥満群のみに有意 な改善が認められた。

高血圧群は非高血圧群に比べ，指導前から「つま久食 い」, 「奨油やソースをかける」人は有意に少なく, 指導

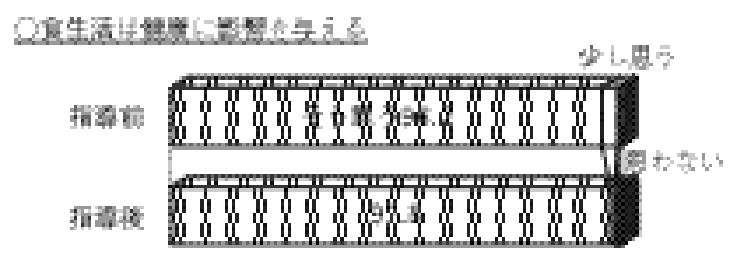

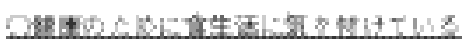

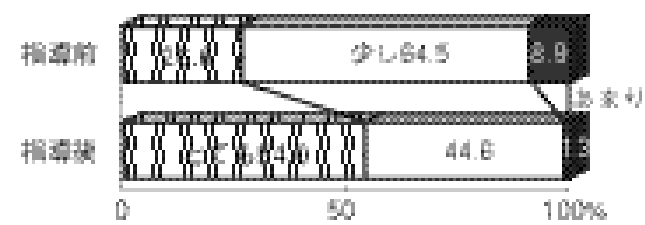

図 1 食意識の指導前後の变化 $(n=372)$
後有意な改善は認められなかった。また，高血圧群では， 「間食をする」人も指導前から非高血圧群に比べ有意に 少なかったが，指導後は更に減少した。両群ともに，指 導後多くの項目で改善が認められ, 特に「塩分に気を使 っている」人は, 高血圧群で指導後全体の 7 割以上に増 加した。

\section{3-3 食品摂取状況}

肥満をたは高血圧有無別の食品や料理の摂取状況で, 指導前後有意に変化した項目の久表 4 に示す。指導前, 肥満群では非肥満群に比べ, 漬物をたっぷり食べる人が 有意に多かったが，指導後有意に減少した。また，野菜， 緑黄色野菜, きのこ類をよく食べる人は, 指導後肥満群 のみに有意な増加が認められた。

高血圧群は非高血圧群に比べ, 指導前から漬物を食べ る人が有意に少なかったが，指導後更に減少した。また， 野菜, 果物をよく食べる人は, 指導後高血圧群のみに有 意な増加が認められた。

\section{考察}

肥満群では, 非肥満群に比べ，好ましい食生活である 人が少なかったが，指導後多くの項目で改善がみられた ことから, 本健康増進教室の受講が自分自身の体型を見 直すきっかけとなり, 実際の行動の変容に結びついたと 考えられる。肥満は, 食事が不規則, 満腹まで食べる, 食べるスピードが速い, 間食が多い, 朝食欠食, 脂質の 摂取が多いなどの食生活が報告されているが8) 13), 本 対象者の肥満群ではこれらの食生活が改善しており,こ のことが肥満の改善につながったと考えられる。

食事の影響を受けやすい総コレステロールや中性脂肪 は, 肥満群で高く14),15), BMI や体脂肪率の減少に伴っ て減少し16),17), BMI 増加が高コレステロール血症や高 中性脂肪血症の出現率と関係していることが報告されて いる18)。本研究では, 総コレステロールや中性脂肪は, 肥満群及び高血圧群ともに指導後顕著に減少しており, 肥満や高血圧の改善が, メタボリックシンドロームの発 症のリスクを低下させたと考えられる。このような指導 前後の変化から, 栄養指導が実際に参加者の食生活, 栄 養状態に影響を与えることが確認できた。

一方, 高血圧群では, 指導前から食生活に気をつけて いた人が多かったことが分かり，健康に対する意識の高 さが伺えた。このため, 指導後に有意に改善した項目は 少なかったが, カリウム供給源となる野菜や果物, カル シウム源である牛乳の摂取, 塩分に関しては有意な改善 がみられ，このような食生活が血圧低下に影響したと考 えられる。なお, 高血圧では, 汁物を控えるように指導 することが一般的であるが, 高血圧群で指導後に汁物の 摂取が増加したにもかかわらず，血圧は顕著に低下して おり, この点に関しては今後の課題と考えている。

また, 本研究では, 食習慣の久を取り上げたが, 本健 康増進教室では運動指導も行って抢り, 指導後には運動 
健康増進事業による受講者の栄養状態改善効果

表 3 食生活の指導前後の変化 一肥満※ままたは高血圧 $* 2$ の有無別一

\begin{tabular}{|c|c|c|c|c|c|c|c|c|}
\hline \multirow[b]{2}{*}{ 項目 } & \multicolumn{2}{|c|}{$\begin{array}{c}\text { 非肥満者 } \\
(\mathrm{n}=97) \\
\end{array}$} & \multicolumn{2}{|c|}{$\begin{array}{c}\text { 肥満者 } \\
(\mathrm{n}=275) \\
\end{array}$} & \multicolumn{2}{|c|}{$\begin{array}{c}\text { 非高血圧者 } \\
(\mathrm{n}=186)\end{array}$} & \multicolumn{2}{|c|}{$\begin{array}{l}\text { 高血圧者 } \\
(\mathrm{n}=186)\end{array}$} \\
\hline & 指導前 & 後 & 前 & 後 & 前 & 後 & 前 & 後 \\
\hline \multicolumn{9}{|l|}{ 食生活 } \\
\hline 夕食時間18時以前 & 9.3 & 10.3 & 5.8 & $11.6^{*}$ & 8.6 & 10.2 & 4.8 & $12.4^{* *}$ \\
\hline 朝食を必ず食べる & 85.6 & 91.8 & 80.0 & $88.0^{* *}$ & 78.0 & $87.1^{*}$ & 84.9 & 90.9 \\
\hline 気に入ったものを続けて食べる & 7.2 & 2.1 & 9.8 & $6.2^{*}$ & & & & \\
\hline 気に入ったものを多量に食べる & 18.6 & 11.3 & $30.2^{\dagger}$ & $14.9^{* * *}$ & 32.3 & $17.2^{* *}$ & 22.0 & $10.8^{*}$ \\
\hline いつも腹いっぱいに食べる & 22.7 & $10.3^{*}$ & $34.5^{\dagger}$ & $12.4^{* * *}$ & 31.7 & $11.8^{* * *}$ & 31.2 & $11.8^{* * *}$ \\
\hline 余り料理をよく食べる & 18.6 & 12.4 & 28.4 & $9.8^{* * *}$ & 30.1 & $12.9^{* * *}$ & 21.5 & $8.1^{* * *}$ \\
\hline 塩分に気を使っている & 48.5 & $69.1^{* *}$ & 42.9 & $71.6^{* * *}$ & 39.8 & $65.1^{* * *}$ & 48.9 & $76.9^{* * *}$ \\
\hline やけ食いすることがある & 35.1 & $21.6^{*}$ & $48.4^{\dagger}$ & $32.0^{* * *}$ & 48.4 & $33.9 *$ & 41.4 & $24.7^{* *}$ \\
\hline つまみ食いをすることがある & 63.9 & 59.8 & 71.3 & $63.6^{* *}$ & 75.8 & $65.1^{*}$ & $62.9^{\dagger}$ & 60.2 \\
\hline 全部食べないと気がすまない & 50.5 & 43.3 & $68.4^{\dagger \dagger}$ & $55.3^{* *}$ & 66.7 & $53.8^{*}$ & 60.8 & 50.5 \\
\hline 奨油やソースをかけることがある & 22.7 & 17.5 & 30.9 & $17.5^{* * *}$ & 35.5 & $18.3^{* * *}$ & $22.0^{\dagger \uparrow}$ & 16.7 \\
\hline ファーストフードを利用する & 57.7 & $40.2^{* *}$ & 54.2 & $43.6^{*}$ & 57.5 & $43.0^{* *}$ & 52.7 & $42.5^{*}$ \\
\hline お酒をよく飲む ～～～～～～～ & 22.7 & $9.3^{*}$ & 13.1 & $5.8^{* *}$ & 18.3 & $6.5^{* * *}$ & 12.9 & $7.0^{*}$ \\
\hline \multicolumn{9}{|l|}{ 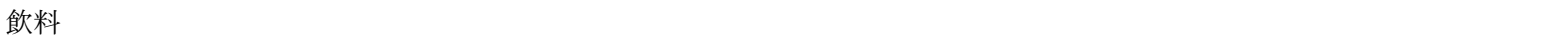 } \\
\hline 清涼飲料水を飲む & 62.9 & $39.2^{* *}$ & 73.8 & $37.8^{* * *}$ & 73.7 & $44.6^{* * *}$ & 68.3 & $31.7^{* * *}$ \\
\hline コーヒー, 紅茶に砂糖を入れる & 41.2 & 28.9 & 39.6 & $30.5^{*}$ & 39.2 & $29.0^{*}$ & 40.9 & 31.2 \\
\hline \multicolumn{9}{|l|}{$\begin{array}{ll}\text { 間食 } \\
\end{array}$} \\
\hline 間食は 2 日に 1 回以上する & 53.6 & $35.1^{* *}$ & 59.3 & $29.8^{* * *}$ & 66.1 & $36.0^{* * *}$ & $49.5^{\dagger \dagger}$ & $26.3^{* * *}$ \\
\hline 夕食後に食べたり飲んだりする & 63.9 & 50.5 & 73.8 & $44.0^{* * *}$ & 74.2 & $53.2^{* * *}$ & 68.3 & $38.2^{* * *}$ \\
\hline
\end{tabular}

※1 非肥満 : $\mathrm{BMI}<25 \mathrm{~kg} / \mathrm{m}^{2}$, 肥満 $: \mathrm{BMI} \geqq 25 \mathrm{~kg} / \mathrm{m}^{2}$

※2高血圧 : 収縮期血压 $\geqq 140 \mathrm{mmHg}$ または拡張期血圧 $\geqq 90 \mathrm{mmHg}$ ，非高血圧 : それ以外

$\uparrow \mathrm{p}<0.05, \quad \uparrow \uparrow \mathrm{p}<0.01$ :

指導前の非肥満-肥満での検討 : 年齢と平均血圧補正, 指導前の非高血圧-高血圧での検討 : 年齢と BMI 補正 ${ }^{*} \mathrm{p}<0.05,{ }^{* *} \mathrm{p}<0.01, * * * \mathrm{p}<0.001:$

指導前後での検討 : 非肥満及び肥満群は年齢と平均血圧補正, 非高血圧及び高血圧群は年齢と BMI 補正

表 4 食品等摂取状況の指導前後の変化 一肥満※1または高血圧※2の有無別一

\begin{tabular}{|c|c|c|c|c|c|c|c|c|}
\hline \multirow[b]{2}{*}{ 項目 } & \multicolumn{2}{|c|}{$\begin{array}{c}\text { 非肥満者 } \\
(\mathrm{n}=97) \\
\end{array}$} & \multicolumn{2}{|c|}{$\begin{array}{c}\text { 肥満者 } \\
(\mathrm{n}=275)\end{array}$} & \multicolumn{2}{|c|}{$\begin{array}{c}\text { 非高血圧者 } \\
(\mathrm{n}=186)\end{array}$} & \multicolumn{2}{|c|}{$\begin{array}{l}\text { 高血圧者 } \\
(\mathrm{n}=186)\end{array}$} \\
\hline & 指導前 & 後 & 前 & 後 & 前 & 後 & 前 & 後 \\
\hline \multicolumn{9}{|l|}{ 食品 } \\
\hline 野菜 & 67.0 & 74.2 & 63.3 & $75.6^{* *}$ & 63.4 & 72.6 & 65.1 & $78.0^{* *}$ \\
\hline 緑黄色野菜 & 32.0 & 41.2 & 33.1 & $44.0^{* *}$ & 30.6 & $43.5^{*}$ & 34.9 & $43.0^{*}$ \\
\hline 果物 ～～～～～～～～～～ & 53.6 & $70.1^{*}$ & 44.4 & $53.8^{*}$ & 41.4 & 50.5 & 52.2 & $65.6^{*}$ \\
\hline きのこ & 27.8 & 39.2 & 27.6 & $43.6^{* * *}$ & 26.9 & $41.4^{* *}$ & 28.5 & $43.5^{* *}$ \\
\hline 海藻 & 29.9 & $50.5^{* *}$ & 38.5 & $49.1^{*}$ & 30.6 & $47.3^{* *}$ & 41.9 & $51.6^{*}$ \\
\hline 肉加工品 & 8.2 & 5.2 & 10.2 & $5.5^{*}$ & 12.4 & $5.9^{*}$ & 7.0 & 4.8 \\
\hline 牛乳 & 66.0 & $81.4^{*}$ & 62.9 & $78.5^{* * *}$ & 64.5 & $79.0^{* *}$ & 62.9 & $79.6^{* *}$ \\
\hline バターやマーガリンたっぷり & 9.3 & 4.1 & 12.0 & $6.9^{*}$ & & & & \\
\hline ドレッシングやマヨネーズ & 23.7 & $12.4^{*}$ & 21.1 & $11.6^{* *}$ & 22.0 & 15.1 & 21.5 & $8.6^{* * *}$ \\
\hline 漬物 & 33.0 & $20.6^{*}$ & 31.6 & $22.9^{*}$ & 36.6 & $24.7^{*}$ & $27.4^{\dagger}$ & 19.9 \\
\hline 漬物たっぷり & 33.0 & 29.9 & $46.5^{\dagger}$ & $28.0^{* * *}$ & 48.4 & $34.9 *$ & $37.6^{\dagger}$ & $22.0^{* *}$ \\
\hline \multicolumn{9}{|l|}{ 料理 } \\
\hline 揚げ物 & 8.2 & 2.1 & 9.5 & $4.7^{*}$ & 11.8 & $3.8^{* *}$ & 6.5 & 4.3 \\
\hline 煮物味付けあっさり & 44.3 & 55.7 & 35.3 & $49.8^{* * *}$ & 35.5 & $48.9^{* *}$ & 39.8 & 53.8 \\
\hline 汁物 & 63.9 & $78.4^{*}$ & 71.6 & $82.9^{* *}$ & 70.4 & $80.1^{*}$ & 68.8 & $83.3^{* *}$ \\
\hline
\end{tabular}

※1非肥満 : $\mathrm{BMI}<25 \mathrm{~kg} / \mathrm{m}^{2}$, 肥満 $: \mathrm{BMI} \geqq 25 \mathrm{~kg} / \mathrm{m}^{2}$

※2高血圧 : 収縮期血圧 $\geqq 140 \mathrm{mmHg}$ または拡張期血圧 $\geqq 90 \mathrm{mmHg}$ ，非高血圧 : それ以外

$\uparrow \mathrm{p}<0.05, \quad \uparrow \uparrow \mathrm{p}<0.01$ :

指導前の非肥満一肥満での検討 : 年齢と平均血圧補正, 指導前の非高血圧-高血圧での検討 : 年齢と BMI 補正

${ }^{*} \mathrm{p}<0.05, * * \mathrm{p}<0.01,{ }^{* * *} \mathrm{p}<0.001:$

指導前後での検討 : 非肥満及び肥満群は年齢と平均血圧補正，非高血圧及び高血圧群は年齢と BMI 補正 
をする人が増加していた。指導後, 血圧が有意に低下, 最大酸素摂取量が増加したことから，栄養指導だけでは なく運動指導も同時に行うことで効果が上がったと考え られる。

以上，健康増進教室への受講が生活習慣を見直すきっ かけとなり, 自分の問題点となる食生活等の生活習慣が 改善され, 継続された結果, 肥満や高血圧の改善, 更に はメタボリックシンドロームや生活習慣病のリスク低下 に有効であることが明らかになった。なお，今後は，教 室参加終了後の身体状況や生活習慣の変化についても追 跡調査を行い，健康増進教室受講の意義を明らかにした いと考えている。

\section{要 約}

健康増進教室受講者の指導前後の栄養状態を比較し, 指導による改善効果を検討した。

北九州市で実施されている健康増進教室では，12週間 の栄養 ·運動指導と, 開始 · 終了時に医学検査と問診を 行っている。今回は，1994～1998年度の受講女性372名 を解析対象とし, 指導前後の食習慣と栄養状態を, 肥満 及び高血圧の有無別に検討した。

対象者は36〜64歳で, 指導前は肥満 $73.9 \%$, 高血圧 50.0 \%であったが，終了時には各々 $61.6 \% ， 26.9 \%$ に減少し， 体脂肪率や血圧, 総コレステロール, 中性脂肪等は有意 に低下，最大酸素摂取量や HDL-コレステロールは有意 に増加した。また, 指導後は, 肥満群でほとんどの食習 慣項目に改善がみられ，指導前から好ましい食生活であ った高血圧群でも, 野菜や果物, 塩分摂取に有意な改善 がみられた。

健康増進教室への受講は, 生活習慣を見直すきっかけ となり，好ましい習慣を身に付けることにより，メタボ リックシンドロームや生活習慣病のリスク低下に有効で あることが分かった。

\section{謝辞}

健康へのパスポート事業の企画・運営にご尽力いただ きました北九州市保健福祉局スタッフの方々，また運動 指導を分担していただきました北九州プリンスホテルス ポーツクラブおよび北九州市エッグ三萩野のスタッフの 方々に深謝いたします。また, 統計解析等についてご指 導・ご助言を頂きました産業医科大学池田正人教授に厚 く御礼申し上げます。

\section{文献}

1）松澤佑次：メタボリックシンドロームの疾患概念：臨床 検査, 49, p.1625-1627（2005）

2）健康日本21企画検討会, 健康日本 21 計画策定検討会：健 康日本21（21世紀に抢ける国民健康づくり運動について）, 健康 ·体力づくり事業財団, 東京 (2002)
3）今後の生活習慣病対策の推進について: 厚生科学審議会 (2005)

4）秋吉美穂子, 大輪陽子, 杉山みち子, 麻生武志 : 更年期 外来受診者のニーズの実態調查 : 更年期障害, 生活習慣病 のリスクとライフスタイルの問題, 日本更年期医学会雑誌, 9, p.30-37 (2000)

5）杉浦浩子, 三井政子, 松波美紀, 松田好美, 杉浦春雄, 井奈波良一, 岩田弘敏 : 35 65歳の女性の更年期の自覚, 健康意識抢よび身体 ·精神症状について, 日本更年期医学 会雑誌， 6, p.179-185（1998）

6) 津田幹夫, 真田光博, 中川仁志, 児玉一郎, 坂下和久, 大濱紘三 : 閉経女性の血清脂質とその影響因子に関する検 討，日本更年期医学会雑誌，10，p.32-39（2002）

7）松山敏剛, 田中美鈴, 伊藤和枝, 今井克巳, 増田 隆, 古賀里利子, 伊藤仁美, 中村元臣 : 肥満婦人の閉経を境に した特徵の差と減量指導の効果, 日本更年期医学会雑誌, 9, p.229-237 (2001)

8）鈴木和枝, 福島恭子：青年期女子における肥満の危険因 子に関する検討一特に食習慣を中心に一，栄養学雑誌，58， p.273-276 (2000)

9）宮武伸行, 西河英隆, 黒瀬恵深, 国橋由美子, 藤井昌史： 肥満に及ぼす生活習慣関連因子の検討, 診断と治療, 89, p. 1179-1182 (2001)

10）長尾慶子, 渋谷 梢, 大久保洋子 : 食生活状況と体内死 亡との関連について一体脂肪率別グループ間の比較一, 健 康·体力・栄養, 5, p.11-16（1998）

11）相川り急子, 彦坂令子, 近藤恵久子, 八倉巻和子：女子 大生の栄養摄取と生活時間一かくれ肥満傾向者の食物摂取 々生活状況，栄養学雑誌，59，p.147-155（2001）

12）徳永勝人, 朝川秀樹, 福井威志, 貞広克彦, 林 功 : 日 本の各地域における肥満 · 糖尿病 - 高脂血症 · 高血圧の頻 度と生活習慣に関する検討, 肥満研究, 9, p.64-69 (2003)

13）田中恵子, 池田順子, 東 あかね, 中澤敦子, 中谷素子, 入江祐子, 松村淳子, 杉野成: 女性住民に打ける肥満之 生活習慣との関連一平成10年度京都府民健康づくり・栄養 調査より一，栄養学雑誌，60，p.195-202（2002）

14）上濱龍也, 今村裕行, 西村千尋, 内田知宏, 宮本徳子, 増田容子, 手島香織, 小畑大吉 : 青年男性の Body Mass Index と血圧 ·血清脂質の関係, 総合健診, 29, p.592-595 (2002)

15）今村裕行, 松原末佐, 皆吉正博, 今井 優, 国方和宏, 中村 伸, 小畑大吉, 森井博之: 体脂肪率と医学的検査值 との関係に基づいた肥満の判定基準, 体力科学, 41, p.7078 (1992)

16）和田高士, 池田義雄 : 体脂肪率減少による血清脂質值の 変化, 健康医学, 12, p.76-79（1997）

17）李 廷秀, 川久保清, 宮本慶子, 佐々木美奈子 : 体重変 化と冠危険因子の関連一中高年男性の 6 年間の健診データ 成績から一，日本公衆衛生誌，46，p.373-378（1999）

18）吉池信男, 西 信雄, 松島松翠, 伊藤千賀子, 池田義雄, 樫原英俊, 吉永英世, 小倉 浩, 小峰慎吾, 佐藤祐造, 佐 藤則之, 佐々木 陽, 藤岡滋典, 奥 淳治, 雨宮禎子, 坂 田利家, 井上修二 : Body Mass Index に基づく肥満の程度 と糖尿病, 高血圧, 高脂血症の危険因子との関連一多施設 共同研究による疫学的検討一, 肥満研究, 6, p.4-17 (2000) 